\title{
Investigating the impact of performance management on human resource performance across head offices of Agricultural bank branches in Tehran
}

\author{
Mir Hamid Reza Torabi Shahidi \\ M.A Student, Faculty of management \\ Islamic Azad University of Tehran, Tehran branch \\ Corresponding Author: mirhamid.torabi@yahoo.com \\ Nasrollah Shabankareh \\ M.A Student, Faculty of Entrepreneurship \\ University of Tehran, Tehran, Iran \\ Email: nasrolla2002@yahoo.ca \\ Ayatollah Momayez \\ Assistant Professor, Faculty of Entrepreneurship \\ University of Tehran, Tehran, Iran. \\ Email: amomayez@ut.ac.ir
}

DOI: $\quad 10.6007 /$ IJARBSS/v3-i8/135 URL: http://dx.doi.org/10.6007/IJARBSS/v3-i8/135

\begin{abstract}
Human resource is one of the most precious assets across contemporary organizations and companies. For this reason, enterprises have to invest on them to promote and improve their employees' performance. An effective mechanism to develop corporate and human performance is to design and establish a system of performance management so that it improves employees' performance by determining explicit organizational objectives and coordinating them with individual goals.

Current work aims to determine the impact of performance management on human resource performance across head offices of Agricultural Bank branches in Tehran (the main goal) and prioritize among performance management components and human resource performance components and also present some procedures to improve human performance using performance management components (sub-goals).

Data collection in this paper was conducted by questionnaires and through libraries and questionnaires were considered as data collection tools. To this respect, a questionnaire containing 30 items was designed based on five-point Likert scale and its validity and reliability were confirmed. Along with data analysis, statistical models including single-variable regression (to examine the impact of performance management on employees' performance), multivariable regression (to investigate the impact of performance management components on


employees' performance), Smirnov Kolmogorov (to address normalization of variables distribution) and Friedman (to rank variables) were used.

The results of current research showed that there is a positive and significant relationship between performance management and employees' performance and also between performance management and components of employees' performance at $\alpha=0.01$ and all research hypotheses were acknowledged. Finally, components of performance management and human performance were prioritized through Friedman test according to which in variable "performance management", components "plan", "do" and "check" respectively were from 1 to 3 ranks and in variable "human performance", components "evaluation", "incentive" and "clarity" were among rank 1 to 3, respectively.

Key words: Performance, performance appraisal, performance management, performance improvement.

\section{Introduction}

Profit making and survival is the goal of establishment of every institute, organization or company. To achieve this end, organizations endeavor to promote their profit by increase productivity of production factors and decreasing their expenses. Today, all nations across the world are seeking to develop in the area of performance improvement and an important debate raised at enterprises is that how does employees' performance level is augmented? What factors will improve human resource performance at a manufacturing or service entity? One useful mechanism for developing organizational and employees' performance is to design and establish a system of performance management. Determining explicit and clear organizational goals, performance management integrates them into common, team or individual goals and regularly reviews them to provide structured and effective management tools (Armstrong, 2002,9) by which we can maximize each unit's, manager's and generally organizational success.

The main problem in our country, Iran, is lack of optimal use of resources despite appropriate facilities, so that a plethora of facilities are wasted and available resources, land and capital are not optimally exploited. As a result, we will see subsidence o performance level in all aspects, particularly, human resources. One of the problems the author faced at head offices of Agricultural Bank was low level of human resource performance which can be under influence of many factors including: occupational dissatisfaction, lack of performance appraisal indicator, existence of discrimination among employees, vocational insecurity, unsuitable working environment, management weakness and so on... but from the author's view, the main factor of low level performance was failure in exercising performance management.

\section{Reason for necessity and importance}

The reason for necessity and importance of this research is that public sector in Iran plays a dominant contribution in national economy so that increases in productivity of this sector significantly affects the entire economy and even procedures of economic affairs in private sector. Since Agricultural Bank is a public organization, development of human resource performance may lead to promotion of performance level and productivity at other levels including: organizational and departmental levels such as industry and agriculture and 
ultimately have optimal effects on the entire national economy. Therefore, improving human resource performance is very important.

\section{Performance definition}

Oxford dictionary defines performance as implementation, execution and accomplishment of every committed or regular thing. This definition not only associates with inputs and outputs but it suggests that performance is associated with accomplishment of affairs and its results. So, performance can be viewed as conduct, a method used by organizations, teams or people to accomplish a job (Armstrong, 2003,11)

\section{Definition of performance appraisal}

Performance appraisal is a process by which a manager measure employees' working behavior, compares it with predetermined appraisal standards, records the results and communicates them to employees (Morhed/ Griffin, 2003, 218).

\section{Definition of performance management}

Performance management is a coherent and strategic process which ensures consistent organizational success by improving employees' performance through development of teams' and participants' capabilities (Armstrong, 2002, 9).

\section{Model and research hypotheses}

In current research, for the independent variable (performance management) we used PDCA model proposed by Deming with components: Plan, Do, Check and Act; and for the dependent variable (human resource performance) we used Hersey's and Goldsmith's ACHIEVE model with components: Ability, Clarity, Help, Incentive, Evaluation, Validity and Environment.

- Main hypothesis

Performance management affects human resource performance.

- Secondary hypotheses

1-Performance management affects ability

2-Performance management affects clarity

3-Performance management affects help

4-Performance management affects incentive

5-Performance management affects evaluation

6-Performance management affects validity

7-Performance management affects environment.

Effective factors on human resource performance

Hersey and Goldsmith introduced 7 variables associated with effective performance management within the framework of ACHIEVE model as follows:

\section{1- $\quad$ Ability or knowledge or skill}

Ability refers to people's knowledge and skills in successful accomplishment of tasks. Employees with better and higher education are able to use the capital more effectively and efficiently and create more products(Hersey \& Blanchard, 1992, 509). 


\section{2- Clarity}

Clarity refers to understanding and acceptance of how and where the job is performed. If we want our employees have a full comprehension of the problem, we should clarify the main goals and the manner of achievement to them.

\section{3- Organizational help}

Employees need organizational help or support to effectively fulfill their tasks. Some factors of organizational help include: budget, equipment and facilities for fulfillment of commitments, necessary support from other departments, availability of product and its quality and sufficient stock of human resource (Hersey \& Blanchard, 1993, 510).

\section{4- Incentive}

It refers to people's interest in doing a specific task in a successful manner Human has several needs and demands some of which are social and some are economic. People need sufficient income and benefits, security, group membership, respect, growth and proliferation, identity and etc, so that provision of some of these demands may promote staff's motivation to realize goals and plans. A method which contributes to recognize remarkable points of extremes is the "remarkable event" trend which involves gathering official evidence regarding extremely positive or extremely negative performances. It guarantees that the subordinates get a feedback which is part of the official criteria (Hersey and Blanchard, 1992, p.511).

\section{5- Evaluation}

Performance appraisal is a process by which employees' performance is formally investigated and measured over given intervals.(Mondy, R.Wayne \&Robert M.Noe, 1987, 366).

\section{6- Validity}

Validity refers to legal decisions made by the manager about human resource. Managers must ensure that decisions concerning employees are suitable in terms of legal code and corporate procedures. Manager must know that legal procedure of management is explicit and decisions should be accompanied by documents or be based on performance-oriented procedures (Hersey \& Blanchard, 1971, 513).

\section{7- Environment}

Environmental factors affecting performance may include competition, changes in marketplace conditions and public regulations. If an environmental problem was out of followers' authority, it is expected that they act consistent with environmental restrictions (Hersey \& Blanchard, 1971, 513).

\section{Dimensions of performance management}

The majority of management systems adopt Deming's consistent improvement cycle (PDCA). This system includes aspects such as planning, doing and operationalization, checking and conducting corrective actions which are described in the following (Biazi, Aghili, Moein, 2005, 53)

\section{1-Planning}

Planning refers to specification and validation of performance conditions (objective, operation statement, scheduling, responsibilities, beneficiaries, colleagues, necessary resources, measurement mechanisms etc.) which is an organizational process to achieve corporate objectives. 


\section{2-Operationalization and trial doing}

One of planning elements is to assign responsibilities and tasks and dependent on the type of activity and operation, if deemed necessary by management, working guidelines have to be prepared for every important task (for example, executive procedure or guidelines for executive measures). After doing the above actions, it is time for trial implementation of plans. After reviewing the results (at check step) one of the following options must be selected: 1. plan acceptance 2. plan refusal 3. redesign. When the experiment was conducted properly, it is time for final implementation of plans(J. Latzco \& M. Sanders,2003, 65).

\section{3-Checking and controlling}

Checking performance is generally conducted to ensure that the enacted plans will be operational. As such, if generally the result of checking was favorable, the issue will improve consistently, if not, it will be corrected (the same source, 53,54).

\section{4-Final and corrective actions}

Operations planning may be conducted to run the processes, improve the projects in different areas, correct an unsuitable area or eradicate the causes of inconsistencies (the same source, 54).

\section{Process of performance management}

Major activities of performance management include:

\section{Role definition}

Role definition determines three aspects: first is the role objective meaning that what is expected from role holder and provides a performance agreement. Secondly, it defines main responsibilities and presents those headlines based on which performance goals and standards are agreed upon. And thirdly, it provides key capabilities indicating the necessary knowledge, skills and behaviors for effective doing of the role (Armstrong, 2003, 32).

\section{1-Performance planning (agreement)}

Performance planning is the starting point of the process of performance management. Planning is conducted for the process of common exploratory performance management about what is expected from people to do (working duties) and to know (knowledge and skill) and their expected behaviors to provide requirements of knowledge and skill development. Performance plan also determines how managers support and guide their employees as necessary.

\section{2-Individual development planning}

Individual planning includes all activities people assume to do, learn and develop. They form and execute plans and are supported by their organizations and managers. The goal of individual development planning is to promote learning and equip people with knowledge and a set of transferable skills which help people along the way (Armstrong, 2003,229).

\section{3-Performance management during (coaching)}

Supervisors in the role of coaches must encourage their subordinates to promote their knowledge, use their common resources and propagate information about their successes and failures over training courses. During such courses, all employees' occupational duties and procedures will be investigated to assure the rationality and practicality of all above cases and employees' support. Otherwise, some alterations can be made in performance plan (Akbari, 2005). 


\section{4-Performance review}

The last step in the process of performance management which is a supplement for the process is to analyze and review employees' performance and behavior in their presence and plan for necessary corrective actions to improve performance over the next terms (Abolalayi, 2006,113)

\section{The difference between performance management and performance appraisal}

Although the notions of performance management and performance appraisal usually overlap, they have fundamental differences to which we have referred in the following table (table 1)

Table1-The difference between performance management and performance appraisal

\begin{tabular}{|c|c|}
\hline Performance appraisal & Performance management \\
\hline Retrospective & Prospective \\
\hline Little association with & Strong relationship with \\
\hline organizational needs & organizational needs \\
\hline Focus on judgment & $\begin{array}{l}\text { - Focus on coaching and supportive } \\
\text { role of managers }\end{array}$ \\
\hline Top-down approach & Cooperative approach \\
\hline $\begin{array}{l}\text { Focus on exploring employees' } \\
\text { mistakes }\end{array}$ & $\begin{array}{c}\text { Focus on employees' } \\
\text { development and training }\end{array}$ \\
\hline $\begin{array}{l}\text { - Little association between } \\
\text { employees' goals and }\end{array}$ & $\begin{array}{l}\text { Strong association between } \\
\text { employees' goals and }\end{array}$ \\
\hline organizational goals & organizational goals \\
\hline $\begin{array}{l}\text { - Emphasis on performance } \\
\text { appraisal }\end{array}$ & $\begin{array}{l}\text { - Emphasis on performance } \\
\text { improvement and planning }\end{array}$ \\
\hline
\end{tabular}

(Armstrong،Gholamzadeh‘Ebili) 
A review of literature

A number of research conducted to this respect are described in the following table:

Table2

\begin{tabular}{|c|c|c|}
\hline Name of researcher & year & The results \\
\hline Eiraj Soltani & 2005 & $\begin{array}{l}\text { Performance management leads to manage all the work } \\
\text { involved in improving their current competencies and } \\
\text { establish a system of communication between the } \\
\text { individual merits of their actual performance }\end{array}$ \\
\hline $\begin{array}{c}\text { Maryam } \\
\text { Fereidoonian }\end{array}$ & 2009 & $\begin{array}{l}\text { Design an appropriate system of payment based on } \\
\text { performance, competence, interpersonal skills, } \\
\text { maintenance manpower, training and human resource } \\
\text { development can enhance the productivity of the } \\
\text { organization. }\end{array}$ \\
\hline Maryam Ostadzadeh & 2008 & $\begin{array}{l}\text { Resolution tasks, guidelines, regulations, and laws and } \\
\text { giving Sufficient authority to employees, lead to improved } \\
\text { performance and increased employee productivity. }\end{array}$ \\
\hline Asad Nooghabi & 1996 & $\begin{array}{l}\text { Evaluation of employee performance by identifying } \\
\text { potential and weaknesses and fix them, leads to maintain } \\
\text { quality of service, increase productivity and increase } \\
\text { workforce skills. }\end{array}$ \\
\hline Gholam Abas Ehsani & 1999 & $\begin{array}{l}\text { There is a significant and direct relationship between } \\
\text { employee performance evaluation and effectiveness, It } \\
\text { means that improving system performance evaluation is } \\
\text { greater job satisfaction, organizational commitment and } \\
\text { lack of desertion }\end{array}$ \\
\hline $\begin{array}{l}\text { Samaneh } \\
\text { Darvish\&Hasan } \\
\text { Alizadeh }\end{array}$ & 2008 & $\begin{array}{l}\text { Implementation of the performance management process } \\
\text { is greatly helped to fix the flaws and imperfections of } \\
\text { traditional approaches and evaluate performance fairly and } \\
\text { awareness of the key functions and staff satisfaction and } \\
\text { motivation of employees }\end{array}$ \\
\hline Lon Steen & 1983 & $\begin{array}{l}\text { Salaries and benefits, leads to improve their job skills and } \\
\text { the maintenance staff profession and Provide feedback, } \\
\text { leads to employees aware of their performance and } \\
\text { effectiveness of their activities. }\end{array}$ \\
\hline Michel J. Lebas & 1995 & $\begin{array}{l}\text { performance management is prior to performance } \\
\text { evaluation and protect its. This process facilitates the } \\
\text { identification criteria and corrective actions and also } \\
\text { provides a clear implementation strategy at all levels of }\end{array}$ \\
\hline
\end{tabular}




\begin{tabular}{|c|l|l|}
\hline & & responsibility. \\
\hline Moynihan \&Pandey & 2003 & $\begin{array}{l}\text { Performance management has a positive effect on } \\
\text { Performance components (environment, organizational } \\
\text { support ,Population and Media ,culture and } \\
\text { decentralization). }\end{array}$ \\
\hline Kloot \& Martin & 2000 & $\begin{array}{l}\text { Strategic performance management, provides a } \\
\text { operational strategic framework .This will allow the } \\
\text { organization to explain the vision and strategy, } \\
\text { Communicate between the tasks and Set goals and develop } \\
\text { the design, efficiency and learning. }\end{array}$ \\
\hline David Otley & 1999 & $\begin{array}{l}\text { In this study, the main focus is on performance } \\
\text { management and organizational performance. Using this } \\
\text { framework, we can develop a useful framework in } \\
\text { analyze of other components of management control } \\
\text { systems. }\end{array}$ \\
\hline
\end{tabular}

\section{Research methodology}

Research method is of survey and cross-sectional nature with an applied objective. Statistical community of this research includes all working employees at head offices of Agricultural bank branches in Tehran among whom 150 subjects were appraised. As the community of study had a uniform character, simple random sampling was used to determine the sample size and sample size was provided 170 people using Cochran's formula. Library and questionnaires were used to collect data and data gathering tool was questionnaire. Reliability of the questionnaire was measured using Chronbach's Alpha method (SPSS software). According to the results, Chronbach alpha coefficient was 0.871 which confirmed reliability of the research tool. Formal validity method was adopted to indicate the validity of the questionnaire, so that the initial questionnaires were distributed among 10 experts including academic educators and managers of head offices of Agricultural Bank and after exercising their corrective views, the validity of questionnaires was confirmed and the final questionnaire was prepared.

\section{Data analysis method}

Along with data analysis, statistical models including single-variable regression (to examine the impact of performance management on employees' performance), multi-variable regression (to investigate the impact of performance management components on employees' performance), Smirnov Kolmogorov (to address normalization of variables distribution) and Friedman (to rank variables) were used. 


\section{Findings}

Regarding the results of descriptive statistics analysis we can state that $28.7 \%$ were in charge of the department, $27.8 \%$ were experts and $18.5 \%$ were in charge of administrative affairs. Also, $50.9 \%$ has 11 to 20 years of record of service, $30.6 \%$ less than 10 years and $18.5 \%$ had more than 21 years of service. Concerning frequency distribution of education, $59.3 \%$ had a bachelor degree, $14.8 \%$ has associate degree, $14.8 \%$ had graduate or higher degrees and $11.1 \%$ had a diploma degree. With respect to frequency distribution of gender variable, $69.4 \%$ were males and $30.6 \%$ were females. And finally regarding the frequency distribution of age, $42.6 \%$ were in the range of $31-35$ years-old, $25.9 \%$ were older than 41 and $16.7 \%$ were between 36 and 40 years old.

According to table 3 and single-variable regression coefficients we can say that there is a positive and significant relationship between performance management and employees' performance and also between performance management and components of employees' performance at level of $\alpha=0.01$ so that by promoting performance management, employees' performance and its components will increase and vice versa. Therefore, hypothesis zero is rejected and the opposite one is confirmed

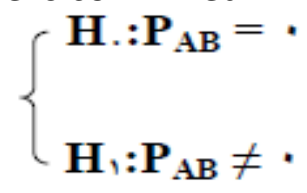

Table 3- single-variable regression for employees' performance and performance management and components of employees' performance

\begin{tabular}{|c|c|c|c|c|}
\hline Significant & $\mathbf{T}$ & Beta coefficient & Predictor variables & Variable \\
\hline $0 / 001$ & $20 / 86$ & $0 / 89$ & performance management & performance \\
\hline $0 / 001$ & $10 / 14$ & $0 / 70$ & performance management & ability \\
\hline $0 / 001$ & $15 / 15$ & $0 / 82$ & performance management & clarity \\
\hline $0 / 001$ & $4 / 67$ & $0 / 41$ & performance management & help \\
\hline $0 / 001$ & $8 / 49$ & $0 / 63$ & performance management & incentive \\
\hline $0 / 001$ & $16 / 71$ & $0 / 85$ & performance management & evaluation \\
\hline $0 / 001$ & $11 / 86$ & $0 / 75$ & performance management & validity \\
\hline $0 / 013$ & $2 / 52$ & $0 / 23$ & performance management & environment \\
\hline
\end{tabular}

With respect to table 4 and regression coefficients which are significant at $\alpha=0.01$, components of performance management have the highest positive and significant relationship with employees' performance and its components which are represented in the following table.

Table 4- multi-variable regression for Component performance management and components of employees' performance 


\begin{tabular}{|c|c|c|c|c|}
\hline Significant & $\mathbf{T}$ & Beta coefficient & Predictor variables & Variable \\
\hline $0 / 001$ & $3 / 71$ & $0 / 34$ & do & \multirow{3}{*}{$\begin{array}{l}\text { employees' } \\
\text { performance }\end{array}$} \\
\hline 0/001 & $6 / 39$ & $0 / 38$ & check & \\
\hline $0 / 001$ & $2 / 86$ & $0 / 16$ & act & \\
\hline $0 / 016$ & $2 / 44$ & $0 / 35$ & do & \multirow{2}{*}{ ability } \\
\hline $0 / 001$ & $4 / 65$ & $0 / 42$ & act & \\
\hline $0 / 001$ & $6 / 63$ & $0 / 70$ & plan & \multirow{2}{*}{ clarity } \\
\hline $0 / 001$ & $3 / 96$ & $0 / 26$ & check & \\
\hline $0 / 001$ & $3 / 64$ & $0 / 69$ & do & help \\
\hline $0 / 004$ & $2 / 93$ & $0 / 43$ & plan & \multirow{2}{*}{ incentive } \\
\hline 0/001 & $6 / 10$ & $0 / 56$ & act & \\
\hline $0 / 001$ & $38 / 53$ & $0 / 92$ & check & evaluation \\
\hline 0/001 & $3 / 35$ & $0 / 46$ & do & \multirow{2}{*}{ validity } \\
\hline 0/001 & $3 / 83$ & $0 / 34$ & check & \\
\hline $0 / 001$ & $3 / 49$ & $0 / 44$ & act & environment \\
\hline
\end{tabular}

\section{Discussion and conclusions}

With respect to the findings and their closeness to the results of other research, we can conclude that performance management affects human resource performance and its components. As a result, the main and secondary hypotheses of current research will be confirmed as follows:

1.According to the findings, there is a significant relationship between performance management and human resource performance and research findings is close with studies Ms. Darwish, Alizadeh(2008). As a result, the main hypothesis is confirmed.

2. According to the findings, there is a significant relationship between performance management and components' ability and research findings is close with the results of research Fereidoonian(2009) and Nooghabi(1996). As a result, the first sub-hypothesis is confirmed.

3. According to the findings, there is a significant relationship between performance management and components' clarity and research findings is close with the results of research Ostadzadeh(2008),Darvish,alizadeh(2008), Michel J.lebas(1995), moynihan and pandey(2003). As a result, the second sub-hypothesis is confirmed.

4. According to the findings, there is a significant relationship between performance management and components' help and research findings is close with the results of research Ostadzadeh(2008), moynihan and pandey(2003). As a result, the third sub-hypothesis is confirmed.

5. According to the findings, there is a significant relationship between performance management and components' incentive and research findings is close with the results of 
research Darvish,alizadeh(2008), Lon steen(1983), Fereidoonian(2009) and David Otley(1999). As a result, the fourth sub-hypothesis is confirmed.

6. According to the findings, there is a significant relationship between performance management and components' evaluation and research findings is close with the results of research Ehsani(1999), Nooghabi (1996), Lon steen(1983) and David Otley(1999). As a result, the fifth sub-hypothesis is confirmed.

7. According to the findings, there is a significant relationship between performance management and components' validity and research findings is close with the results of research Fereidoonian(2009) ,Darvish and alizadeh(2008). As a result, the sixth sub-hypothesis is confirmed.

8. According to the findings, there is a significant relationship between performance management and components' environment and research findings is close with the results of research Fereidoonian(2009), moynihan and pandey (2003). As a result, the seventh subhypothesis is confirmed.

\section{References}

1- Abili, khodayar and Movafaghi, Hasan, Human Resource Management, Tehran, first edition, Publishing Industrial Management, 2010.

2- Abolalaee, Behzad., Performance Management Guide managers for Assessing and Improving Employee Performance, Tehran, first edition, Publishing Industrial Management,2010.

3- Armstrong, Michael, Performance Management, , translated by Dr.Ghelichkhani and Dr.Daryoosh Gholamzadeh,first edition,Tehran,Iran Industrial Research and Publication Centre, 2006.

4- Barnow ,Burt S, Exploring the Relationship between Performance Management and Program Impact: A Case Study of the Job Training Partnership Act, Journal of Policy Analysis and Management, No. 1, 2000.

5- Buccal, Robert, Performance Management, translated by Farshid Ghahremani, first edition, Tehran, Publications mosalath, 2008.

6- Gholamzadeh, Daryoosh ,Web Performance Management, 2010.

7- Hersey, Paul and K. Blanchart, Management Organizational Behavior, Tehran, Majed publications, 1992 .

8- J.lebas,Michel,Performance Measurement and Performance management, Production Economics ,No.41,1995.

9- Jay Latzko, William, Sanders, David, four days Deming, , translated by A. Radnzhad, second edition, Tehran, Amoozeh publications, 2007.

10- Kerlynjer,fered, Principles of Research in Behavioral Sciences, Volume 1, translated by Hossein Pasha Sharifi and J. Najafi Zand,Avaye noor publication, Tehran, 1998.

11- Khaki Gholamreza., Productivity Management, sixth edition, Tehran, Publications Koohsar,2007.

12- Koot, Louise and Martin, John, Strategic performance management:A balanced approach to performance management issues in local government, Academic Press,No. 11,2000.

13- Mirsepasi, Nser., Strategic Management of Human Resources and Labor Relations, Fifth Edition, Tehran, Mir Publishers, 2010. 
14- Moghimi, Seyed Mohamad,Ramezan, Majid, Foundations of organization and Management Journal, first edition, Tehran, publisher of Rahdan, 2011.

15- Moorhead, Griffin, Organizational Behavior, translated by Dr.Mehdi Alvani and G.reza Memarzadeh, twelfth edition, Tehran, Morvarid publications,2007.

16- Moynihan, Donald P and Pandey, Sanjay K, Testing How Management Matters in an Era of Government by Performance Management, Journal of Public Administration Research and Theory, no. 3,2005.

17- Office of Improvement Management and performance appraisal the Department of Human Resource management, performance evaluation, (paper), Management and Planning Organization, 2003.

18- Otley, David, Performance management: a framework for management control systems research , Academic Press,No.10,1999.

19- Pollitt,Christopher, Performance management in Practice, Oxford University Press,no.44,2005.

20- Rezaeian, Ali, Management of Organizational Behaviour, Concepts, Theories and Applications, Tehran, Tehran faculty of management publications, 1995.

21- Soltani, Iraj., performance management and enforcement mechanisms in producing quality, Journal of Management Studies, No. 41 and 42, 2004. 